\title{
The Ituwa Surge deposits of the Holocene Ngozi caldera, Mbeya Region, Tanzania
}

\author{
N. Lenhardt* and G.-J. Peeters
}

Department of Geology, University of Pretoria, Private Bag X20, Pretoria 0028, South Africa

e-mail: nils.lenhardt@up.ac.za

\section{A. S. Macheyeki}

Geological Survey of Tanzania, Ministry of Energy and Minerals, P.O. Box 903, Dodoma, Tanzania
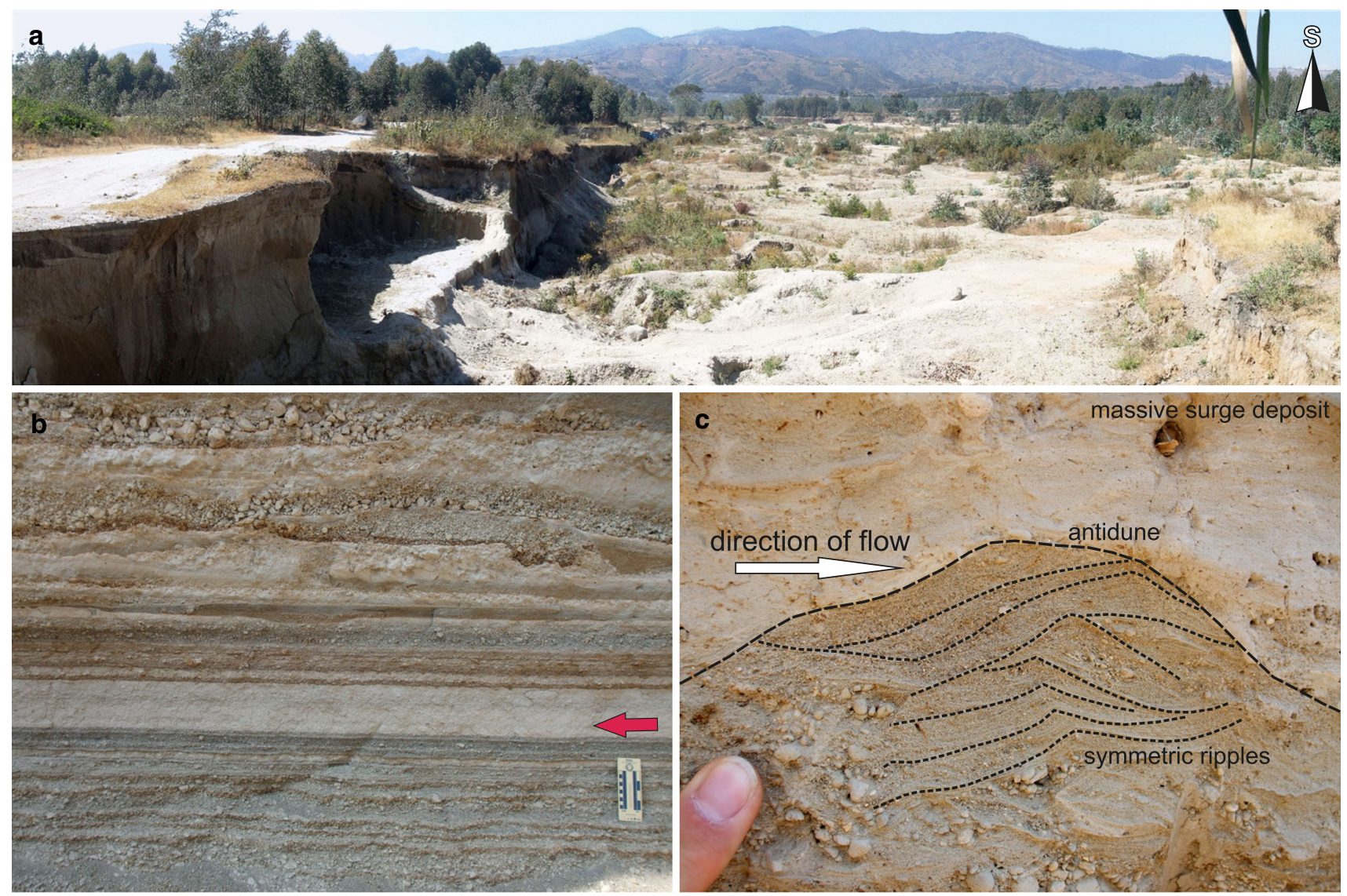

Fig. 1 a Panoramic view of the Ituwa quarry and its medial Ituwa Surge deposits with its source area, the Ngozi caldera, in the background (picture taken from coordinates: $\mathrm{S}^{\circ} 56^{\prime} 25.5^{\prime \prime}$, E33 $33^{\prime} 22.8^{\prime \prime}$ ), b the surge deposits showing an upward change from thinly bedded planar bed forms at the base to abundant dune forms at the top (coordinates: S8囚56037.000, E33®30025.900), c typical small-scale feature as it can be seen in the Ituwa Surge deposits with symmetric ripples growing into an antidune 
The Ituwa Surge deposits belong to the Holocene Ngozi volcano (volcano number 222164 of the Smithsonian Institute Global Volca-nism Program; Siebert et al. 2010) of the Rungwe Volcanic Province (RVP; Harkin 1960; Lenhardt and Oppenheimer 2014). They are named after their type locality and place of best exposure, the village of Ituwa in the Mbeya Region of southwestern Tanzania. Volcanism within the RVP started approximately $9 \mathrm{Ma}$ ago and can be divided into a Late Miocene ( 9.2-5.4 Ma), a Late Pliocene-Early Pleisto-cene ( 3-1.6 Ma) and a Mid-Pleistocene-recent (< 0.6 Ma) phase (Ebinger et al. 1989, 1993; Ivanov et al. 1999).

The trachytic-to-phonolitic Ngozi volcano contains a 3-km-wide caldera with a $1.5 \times 2.75 \mathrm{~km}$ lake in the southern part of the caldera. Ngozi lake is the second largest crater lake in Africa. The caldera is bounded by steep-walled cliffs 150$300 \mathrm{~m}$ high and could be of Holocene age due to its irregular shape (c.f. Fontijn et al. 2012). Only two of Ngozi's deposits could be dated so far through radiocarbon analysis, the 10-12 ka Kitulo Pumice (a fallout deposit) and the $<1$ ka Ngozi Tuff (a pyroclastic density current deposit; Fontijn et al. 2010). The exact relationship between the Ituwa Surge deposits and the two dated Ngozi deposits remains unclear. However, regional stratigraphy suggests that the Ituwa Surge deposits have an age closer to the Ngozi Tuff than the Kitulo Pumice. This deposit may therefore represent a part of the most recent history of the caldera.

In the field, the Ituwa Surge deposits can only be observed north of the caldera toward Mbeya. Here, they provide excellent outcrops in median ( $\mathrm{S} 8^{\circ} 56^{\prime} 37.0^{\prime \prime}$, E33 $30^{\prime} 25.9^{\prime \prime}$; ca. $8.6 \mathrm{~km}$ from caldera center) to distal distances $\left(\mathrm{S}^{\circ} 55^{\prime} 6.6^{\prime \prime}, \mathrm{E} 33^{\circ} 22^{\prime} 27.1^{\prime \prime}\right.$; ca. $22 \mathrm{~km}$ from caldera center) away from the volcano. The deposits can be characterized as base surge deposits similar to the world-famous surge-dominated Mendig facies of Laacher See in Germany (e.g., Schmincke et al. 1973, 1990) and are so far the only recorded deposits of its kind from a Holocene caldera on the African continent. Base surges are dilute pyroclastic density currents (PDCs) that form during phreatomag-matic eruptions, i.e. when rising, magma explosively interacts with subsurface or surface water (Morrissey et al. 2000). They are turbu-lent, ground-hugging clouds of gas and tephra that travel radially away from an explosive center (Wohletz and Sheridan 1979; Wohletz 1998; Mastin and Witter 2000).

Figure 1a shows an overview of the Ituwa quarry outcrop with a view from north to south toward the Ngozi caldera. The deposits at this location are typically characterized by thinly bedded planar bed forms, abundant lithics, induration and strong tephra alteration (pal-agonitization) at the base (Fig. 1b). The arrow points to a layer with high amounts of accretionary lapilli. These layers can be described as "wet surge" deposits (Wohletz and Sheridan 1983). Toward the top, these layers grade into "dry surge" deposits (Wohletz and Sheridan 1983), characterized by abundant dune forms, are poorly to non-indurated and show lower amounts of lithics and palagonitization. Figure 1c shows the successive evolution from symmetric ripples to an antidune which in turn is covered by a massive surge deposit.

Figure 2 (view from the North towards the South) shows an out-crop with the distal Ituwa Surge deposits (overlying the deposits of a debris flow), characterized by predominantly planar bedded to mas-sive, fine-grained deposits.

The deposits are easily accessible and provide an excellent opportunity, in particular, for African geologists/ volcanologists, to study the proximal-distal relationships of the products of base surges originating from violent caldera eruptions.

\section{References}

Ebinger CJ, Deino AL, Drake RE, Tesha AL (1989) Chronology of volcanism and rift basin propagationRungwe Volcanic Prov-ince, East Africa. J Geophys Res 94:15785-15803

Ebinger CJ, Deino AL, Tesha AL, Becker T, Ring U (1993) Tectonic controls on rift basin morphology-evolution of the northern Malawi (Nyasa) Rift. J Geophys Res 98:17821-17836

Fontijn K, Ernst GGJ, Elburg MA, Williamson D, Abdallah E, Kwelwa S, Mbede E, Jacobs P (2010) Holocene explosive eruptions in the Rungwe Volcanic Province, Tanzania. J Volcanol Geotherm Res 196:91-110

Fontijn K, Williamson D, Mbede E, Ernst GGJ (2012) The Rungwe Volcanic Province, Tanzania-a volcanological review. J Afr Earth Sci 63:12-31

Harkin DA (1960) The Rungwe Volcanics at the Northern End of Lake Nyasa. Geol Surv Tanganyika Mem 2:1-172 


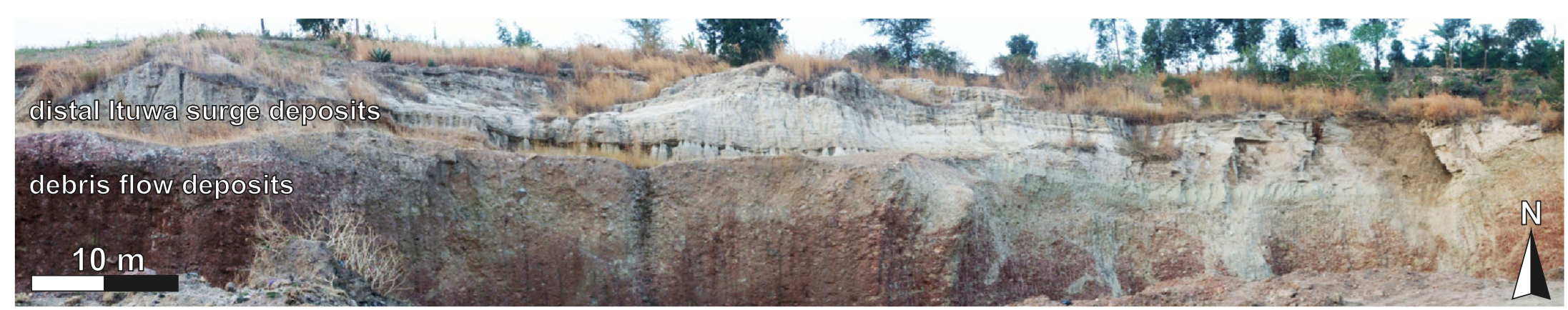

Fig. 2 Panoramic view of the distal Ituwa Surge deposits near the town of Mbalizi (coordinates: S8 $55^{\prime} 6.6^{\prime \prime}$, E $33^{\circ} 22^{\prime} 27.1^{\prime \prime}$ ) 
Ivanov AV, Rasskazov SV, Boven A, Punzalan L, Brandt IS, Brandt SB, Fernandez-Alonso M (1999) Timing and Late Cenozoic volcanic activity and rift basin formations in the Rungwe province of Tanzania substantiated by KAr and 40Ar/39Ar dating. In: Proceedings of Rifting in Intracontinental Setting: Baikal Rift System and other Continental Rifts, 22-30 August 1999, Irkutsk and Lake Baikal, Russia, pp 75-79

Lenhardt N, Oppenheimer C (2014) Volcanism in Africa: geological perspectives, hazard assessment and societal implications. In: Ismail-Zadeh A, Urrutia-Fucugauchi J, Kijko A, Takeuchi K, Zaliapin I (eds) Extreme natural hazards, disaster risks and societal implications, IUGG Special Publication Series. Cambridge University Press, Cambridge, pp 169-199

Mastin LG, Witter JB (2000) The hazards of eruptions through lakes and seawater. J Volcanol Geotherm Res 97:195-214

Morrissey M, Zimanowski B, Wohletz K, Buettner R (2000) Phreatomagmatic fragmentation. In: Sigurdsson H, Houghton

B, McNutt SR, Rymer H, Stix J (eds) Encyclopedia of Volcanoes. Academic Press, London, pp 431-445

Schmincke H-U, Fisher RV, Waters AC (1973) Antidune and chute and pool structures in base surge deposits from the Laacher See

area (Germany). Sedimentology 20:1-24

Schmincke H-U, van den Bogaard P, Freundt A (1990) Quaternary Eifel Volcanism. Excursion guide, workshop in explosive volcanism. IAVCEI International Volcanology Congress Mainz (FGR), Pluto Press, Witten, pp 1-188

Siebert L, Simkin T, Kimberly P (2010) Volcanoes of the World, 3rd edn. University of California Press, Berkeley

Wohletz KH (1998) Pyroclastic surges and compressible two-phase flow. In: Freundt A, Rosi M (eds) From magma to tephra. Elsevier, Amsterdam, pp 25-51

Wohletz KH, Sheridan MF (1979) Model of pyroclastic surge. Geol Soc Am Pap 180:177-194

Wohletz KH, Sheridan MF (1983) Hydrovolcanic explosions II. Evolution of basaltic tuff rings and tuff cones. Am J Sci 283:385-413 